ReVISTA de BIOLOGía TROPICAL

\title{
Two-year temporal response of benthic macrofauna and sediments to hypoxia in a tropical semi-enclosed bay (Cienfuegos, Cuba)
}

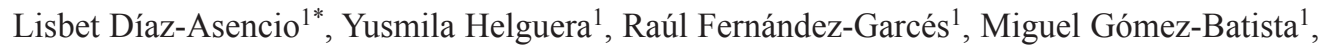 \\ Guillermo Rosell ${ }^{1}$, Yurisbey Hernández ${ }^{1}$, Anabell Pulido ${ }^{1} \&$ Maickel Armenteros $^{2}$ \\ 1. Centro de Estudios Ambientales de Cienfuegos, Ministerio de Ciencia, Tecnología y Medio Ambiente, Carretera a \\ Castillo de Jagua Km 1.5, CP59350, Ciudad Nuclear, Cienfuegos, Cuba; lisbet@ceac.cu, yusmilahelguera@ceac.cu, \\ rfg@gestion.ceac.cu, miguel@ceac.cu \\ 2. Centro de Investigaciones Marinas, Universidad de La Habana, 16 \# 114, CP11300, Playa, Habana, Cuba; \\ maickel@cim.uh.cu
}

Received 24-III-2015. C Corrected 05-VIII-2015. Accepted 08-IX-2015.

\begin{abstract}
Hypoxia is the depletion of dissolved oxygen below $2 \mathrm{mg} \mathrm{O}_{2} / \mathrm{L}$. Relatively few studies on hypoxia and its effects on benthic macrofauna have been done in tropical marine ecosystems. This study describes the temporal response of the water column, sediments and macrofauna to seasonal hypoxia in a semi-enclosed bay (Cienfuegos, Caribbean Sea). The Calisito site was sampled monthly from June 2010 until February 2012, yielding 21 sampling times. At each sampling event water and sediment samples were collected for measuring the abiotic variables (temperature, salinity, dissolved oxygen, nutrients, redox potential discontinuity, silt/clay and organic matter content) and macrofauna (abundance and species richness). Temperature and surface salinity followed a typical temporal pattern during the summer/rainy and the winter/dry periods. Salinity stratification occurred in the rainy period, lasting three months in 2010 and six months in 2011 . The bottom water dissolved oxygen indicated hypoxic and anoxic events during the wet periods of 2010 and 2011 associated with salinity stratification, low hydrodynamics and oxidation of the accumulated organic matter. Over the study period, 817 individuals were collected and identified. Polychaetes were the dominant group in terms of abundance $(57 \%$ of total) followed by mollusks (41\%). Hypoxia (and occasionally anoxia) caused strong deleterious effects on the abundance and species richness of macrofaunal communities in the study site. The most abundant polychaetes were opportunistic species with high tolerance to hypoxic conditions: Prionospio steenstrupi, Polydora sp.and Paraprionospio pinnata. Most of them colonized relatively fast once hypoxia ended. Persistent species such as Caecum pulchellum and Parvanachis obesa were present during hypoxia with fluctuating densities and apparently recover to higher abundances when normoxic conditions are re-established. Macoma tenta and Tellina consobrina colonized approximately 1-2 months later than the first polychaete peak during normoxia. Probably, the deleterious effects of hypoxia on the macrofauna were intensified by negative interspecific relationships such as competition by suitable space and predation. The recolonization of macrofauna depended possibly on local transport by currents within the bay because the connection with the Caribbean Sea is relatively limited. In summary, seasonal hypoxia in Cienfuegos Bay influences the water and sediment geochemistry and reduces both the abundance and diversity of macrofauna. Rev. Biol. Trop. 64 (1): 177-188. Epub 2016 March 01.
\end{abstract}

Key words: oxygen deficiency, organic enrichment, redox potential, polychaetes, mollusks, Caribbean Sea.

Hypoxia is the depletion of dissolved oxygen below $2 \mathrm{mg} \mathrm{O}_{2} / \mathrm{L}$ (Rabalais et al., 2010) and is a pervasive and widespread disturbance in the world ocean (Zhang et al., 2010). There is a growing body of literature regarding hypoxia and its deleterious effects on marine ecosystems, with several recent reviews and syntheses (e.g. Zhang et al., 2010; Howarth et al., 2011).

Oxygen depletion particularly influences the functioning of marine ecosystems (Seitz, Dauer, Llansó, \& Long, 2009; Howarth et al., 2011). For instance, chemical species (e.g. $\mathrm{H}_{2} \mathrm{~S}, \mathrm{CH}_{4}, \mathrm{~N}_{2} \mathrm{O}$ ) associated with microbial 
heterotrophic metabolism predominate, $\mathrm{pH}$ of bottom water decreases and ecosystem energetics change with most of the energy flowing through anaerobic microbial webs (Díaz \& Rosenberg, 2008; Zhang et al., 2010). The benthic community response to hypoxia is primarily the reduction of the overall abundance and the dominance of tolerant groups such as nematodes and polychaetes (Díaz \& Rosenberg, 1995; Vaquer-Sunyer \& Duarte, 2008; Levin et al., 2009).

Natural hypoxia occurs in some ecosystems such as continental margins with upwelling and fjords (Rabalais et al., 2010). However, in coastal areas where human settlements have modified the environment, hypoxia is strongly dependent on anthropogenic activities (e.g. damming, use of fertilizers, urban effluents) (Rabalais et al., 2010). Moreover, in semi-enclosed bays the reduced exchange with the open sea promotes water stagnation and reinforces hypoxic conditions (Yoshino et al., 2010) which may result in total absence of oxygen (i.e. anoxia). Semi-enclosed tropical areas are particularly prone to hypoxia because the higher water temperatures promote oxygen depletion.

Relatively few studies on hypoxia have been done in tropical marine ecosystems (e.g. Jacinto et al., 2011) and, to date, nothing has been published about hypoxia in the coastal Caribbean basin. Our study can therefore help to complete a picture of the hypoxia phenomenon in this poorly studied tropical region. In this context, we focus on Cienfuegos Bay (Cuba Island, Caribbean Sea), a shallow tropical bay in which the signals of hypoxic events have been increasing in the last two decades. The temporal development of hypoxia is poorly known in this bay despite a monitoring program that has been ongoing since the 1990s. Previous findings indicate a summer decrease of dissolved oxygen in bottom waters and occasional anoxia in some deep sites (Seisdedo, 2006); however, the monthly dynamics of oxygen and its effects on the benthos have never been studied. This is the first study linking directly hypoxia with macrofauna diversity in the Caribbean region.

Hypoxia clearly negatively affects macrofauna diversity and abundance in a variety of habitats and conditions. The present study is therefore designed: (1) to describe the temporal dynamics of oxygen-related variables in water and sediments in Cienfuegos Bay; and (2) to describe the response of the macrofauna, in terms of abundance and diversity, to hypoxia here.

\section{MATERIALS AND METHODS}

Study zone: Cienfuegos Bay is a tropical semi-enclosed system with a permanent but weak connection to the Caribbean Sea. The bay has a surface area of $90 \mathrm{~km}^{2}$, an average depth of $14 \mathrm{~m}$ and a sill of ca. $1.5 \mathrm{~m}$ depth that divides it into two basins. The oceanographic regime is strongly seasonal, with salinity stratification of the water column in the wet period (typically June-October) due to river runoff and rainfalls (Seisdedo, 2006). The circulation in the dry season (typically November-May) is governed by wind-driven surface flows and semidiurnal tidal currents (Tomczak \& García-Díaz, 1975; Muñoz, Douillet, Díaz-García, Ouillon, \& Fichez, 2008). During the wet season, the circulation is influenced by river runoff, with very shallow surface flows and water stagnation in the deeper zones of the Northern basin (Tomczak \& García-Díaz, 1975). The water exchange rate of the bay is relatively slow; it shows seasonal differences (39 days in the wet season vs. 50 days in the dry) and spatial variations (Northern basin renewal slower than Southern) (Muñoz et al., 2012).

Sewage discharge is currently an important source of organic matter into the bay due to industrialization and a rapid and poorly regulated program of urbanization since the 1970s. Moreover, population growth has occurred but no wastewater treatment systems in urban settlements expansion and improvements have been made (Anonymous 2000). Thus different creates sewage sources discharge into the bay (i.e. Damují, Salado, Caunao and Arimao): 
the oil refinery, the power plant and the urban effluents from Cienfuegos City.

The study was done at Calisito station in the North basin of the bay (GPS coordinates $\left.22^{\circ} 07^{\prime} 58^{\prime \prime} \mathrm{N}-80^{\circ} 29^{\prime} 49^{\prime \prime} \mathrm{W}\right)$. The site is $10 \mathrm{~m}$ deep and consists of mostly muddy and organically enriched sediments. It is representative of other muddy-deep areas in the bay as suggested by previous studies of our research group (e.g. Díaz-Asencio et al., 2009; Helguera et al., 2011). This makes the drawn inferences useful to understand the temporal dynamics of hypoxia and macrofauna response in the soft-bottoms of this system even though we examined only a single site.

Sampling and measures in situ: The Calisito site was sampled monthly from June 2010 until February 2012, yielding 21 sampling times. At each sampling event a single sample of surface and bottom water were collected for the in situ measurement of temperature, salinity and dissolved oxygen at $50 \mathrm{~cm}$ below the water surface and at $50 \mathrm{~cm}$ above the bottom; samples were collected with a 5 L Niskin bottle. Temperature and salinity were measured using an HYDROLAB probe (accuracy $0.1{ }^{\circ} \mathrm{C}$ and $0.1 \mathrm{psu}$, respectively), and dissolved oxygen was measured by the Winkler titrimetric method (APHA, 1998). The surface sample was used for measuring chlorophyll $a$ and inorganic nutrients (nitrate, nitrite, ammonium and phosphate). The samples were frozen $\left(-20^{\circ} \mathrm{C}\right)$ immediately after sampling until measurement in the laboratory.

Three samples of the top $3 \mathrm{~cm}$ of sediment were collected to measure silt/clay $(\mathrm{S} / \mathrm{C})$ and total organic matter (TOM); samples were collected approximately $5 \mathrm{~m}$ apart by SCUBA divers using plastic cores $(3.6 \mathrm{~cm}$ diameter and $6 \mathrm{~cm}$ long). Three sediment cores were taken monthly to measure the redox potential (Eh); samples were collected by SCUBA divers using transparent plastic cores $(8 \mathrm{~cm}$ diameter and $30 \mathrm{~cm}$ long). The cores were kept in ice and Eh measured in the laboratory within 1-2 $\mathrm{h}$ after collection. Three samples for macrofauna were collected using a Van Veen grab $\left(0.026 \mathrm{~m}^{2}\right)$ and the whole sample preserved immediately in $4 \%$ buffered formalin.

Sample processing: All the chemical determinations were conducted at the Laboratory of Environmental Analyses of the Centro de Estudios Ambientales de Cienfuegos (accredited according to the Cuban standard NC ISO/IEC 17025:06). Chlorophyll $a$, nitrate, nitrite, and ammonia were determined following the standard methods described in APHA (1998), whereas phosphate concentrations were determined by the methods proposed by ASTM (1992). All measurements were completed within $24 \mathrm{~h}$ of sampling. Water was filtered onto $\mathrm{GF} / \mathrm{F}$ filters for chlorophyll $a$ determination, the pigments were extracted with $95 \%$ methanol and the fluorescence measured at $670 \mathrm{~nm}$ before and after acidifying the sample (Turner Designs Instruments). The inorganic nutrients were determined colorimetrically by using a G10SUV-Vis spectrophotometer (Thermo Scientific). Nitrate was determined based upon reduction to nitrite using hydrazine, and then nitrite was determined through formation of a reddish purple azodye measured at 543 nm (APHA, 1998). Ammonia was determined through its reaction with hypochlorite and phenol and then measuring the formed indophenol compound at $630 \mathrm{~nm}$. Inorganic phosphate was determined through formation of molybdenum blue measured at $640 \mathrm{~nm}$.

The silt/clay fraction in the sediment was measured by the gravimetric method after wet sieving through $63 \mu \mathrm{m}$ mesh sieve (Loring \& Rantala, 1992). The total organic matter content was estimated by loss of weight on ignition at $550{ }^{\circ} \mathrm{C}$ for $4 \mathrm{~h}$ and expressed as percentage of the dry weight of the sediment (\% DWS) (Heiri, Lotter, \& Lemcke, 2001).

The redox potential was measured using a RD-N glass redox microelectrode with a steel needle (tip diameter $1.1 \mathrm{~mm}$ ), a REFRM silver/silver chloride open-ended reference electrode (tip diameter about $8 \mathrm{~mm}$ ) and a $\mathrm{pH} /$ $\mathrm{mV}$-meter, all of them from UNISENSE. The Eh electrode was coupled to a manual micromanipulator in order to enable a smooth and 
controlled insertion inside the sediment core. The Eh was measured at intervals of $1 \mathrm{~mm}$ from the sediment surface to the depth where no further changes occurred (ca. $50 \mathrm{~mm}$ deep in normoxic conditions and ca. $20 \mathrm{~mm}$ in hypoxic conditions); Eh values were recorded only when stable values occurred. At least one Eh replicate per month had to be discarded because of the sediment heterogeneity and/or measurement errors of the Eh electrode; only one Eh replicate was valid in November and December 2010. The redox potential discontinuity (RPD) layer was defined as the depth where the first negative Eh value occurred (Fenchel \& Riedl, 1970).

Macrofauna samples were wet sieved through a $0.5 \mathrm{~mm}$ mesh sieve with filtered water (50 $\mu \mathrm{m}$ mesh sieve). The material retained was preserved in $70 \%$ ethanol and $1 \%$ Rose Bengal solution was added to stain the animals. The organisms were sorted and identified to the lowest possible taxonomic level under a stereomicroscope. The identification guides by Abbott (1974) and Redfern (2001) were used for mollusks and Foster (1971) for polychaetes.

We plotted the temporal course of the measured variables from June 2010 until February 2012 (i.e. 21 months). The mean and ranges were computed for the replicated measurements and the coefficient of variation (CV) of the mean was calculated when appropriate. This procedure was done for all the variables except species richness. The species richness was assessed using presence/absence data of species in each month using the program EstimateS (Colwell, 2006). We summed the three replicates in each month to obtain the most completed species list.

We identified the sets of species that most contribute to the similarity within groups of months (i.e. normoxia and hypoxia) applying the procedure SIMPER in the program PRIMER 6.1.14 (Clarke \& Gorley, 2006). Similarity within groups was assessed by the Bray-Curtis similarity index with untransformed data and the cut off for the species contribution was set at $90 \%$ of cumulative similarity.
Bivariate Spearman rank correlations were performed in order to explore the relationships between variables; for macrofauna density, $\mathrm{RPD}, \mathrm{TOM}$ and $\mathrm{S} / \mathrm{C}$, the replicates were averaged within each month. The alpha significance level was adjusted due to the high number of comparisons following the Bonferroni correction method.

\section{RESULTS}

Abiotic setting: Temperature followed a typical temporal pattern with the highest values during the summer rainy period (June-October) and the lowest during the winter dry period (November-May). Both surface and bottom temperature showed a similar pattern; interestingly, in some few months the bottom temperature was higher than surface temperature (Fig. 1A). The surface salinity also had a strong temporal pattern with the lowest values in the rainy period and the highest values in the dry period (Fig. 1B). Vertical stratification occurred in the rainy period, lasting three months in 2010 and six months in 2011. The bottom water salinity decrease in the wet period of 2010 following the trend of the surface salinity, but it was quite stable during the wet period of 2011 despite of the relatively large decrease in the surface salinity.

The dissolved oxygen in the surface water ranged from 5 to $8 \mathrm{mg} \mathrm{O}_{2} / \mathrm{L}$ with the maximum values in the dry period and the lowest in the wet period. The bottom water dissolved oxygen indicated hypoxic and anoxic events during the wet periods of 2010 and 2011 (Fig. 1C). The minimum values of the redox potential discontinuity depth occurred in July-November of 2010 and 2011 (Fig. 1D). During these periods, the sediment had a strong smell of $\mathrm{H}_{2} \mathrm{~S}$ (as inferred from collected cores) and was covered by a patchily distributed reddish filamentous layer of 2-3 mm thickness. Further qualitative analysis of the layer identified the diatoms Nitzschia sp. and Diploneis sp. and the cyanobacteria Arthrospira sp.

The total organic matter content in sediment was relatively stable through the study. 

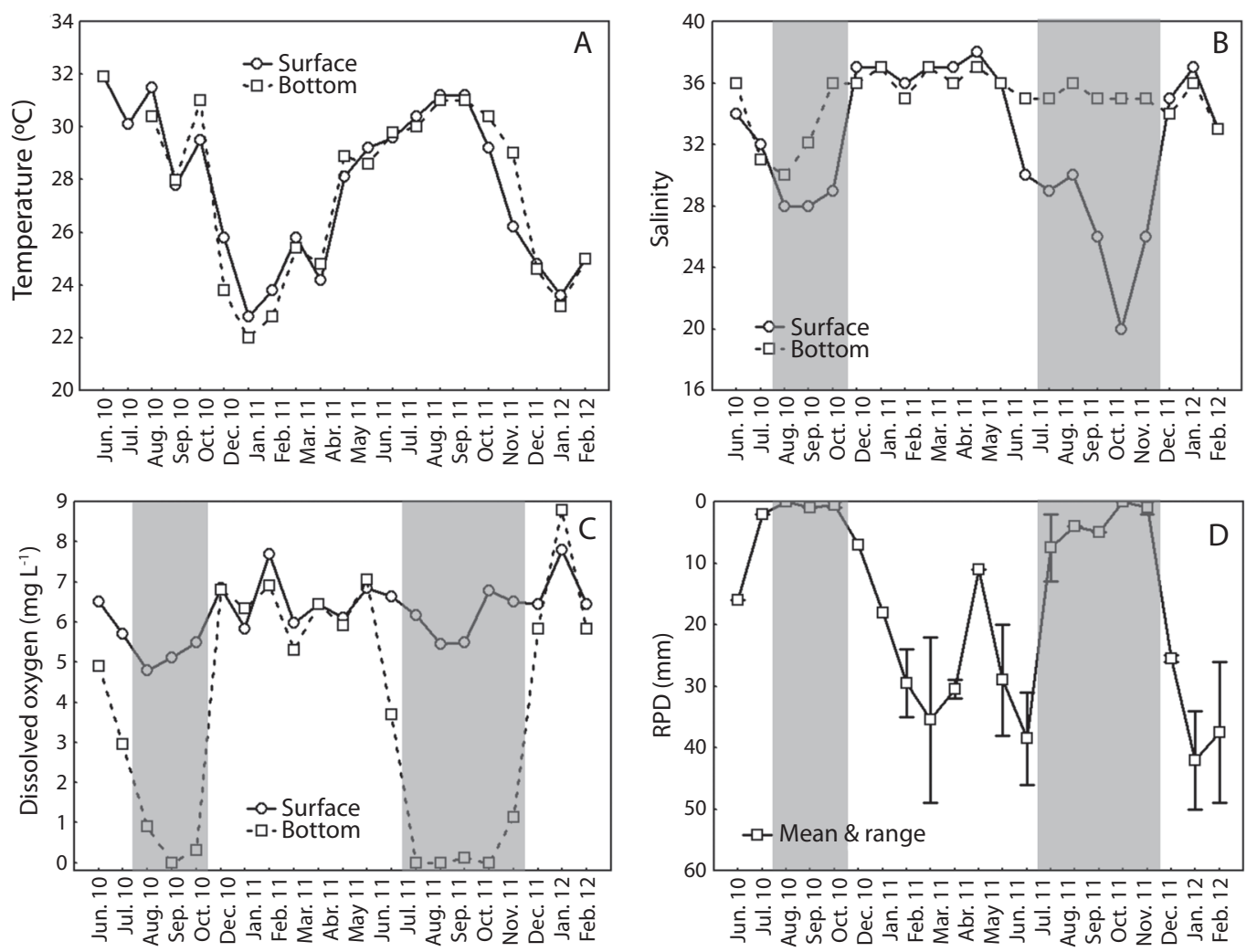

Fig. 1. Temporal fluctuations of the abiotic variables during two years of sampling. (A) Temperature, (B) Salinity, (C) Dissolved oxygen, (D) Redox potential discontinuity depth $(\mathrm{RPD}, \mathrm{n}=2)$. Shaded areas indicate hypoxic conditions in bottom water (dissolved oxygen $<2 \mathrm{mg} / \mathrm{L}$ ). The depth of the study site is $10 \mathrm{~m}$.

Fig. 1. Fluctuaciones temporales de las variables abióticas durante los dos años de muestreo. (A) Temperatura, (B) Salinidad, (C) Oxígeno disuelto, (D) Profundidad de la Discontinuidad Redox (RPD, $\mathrm{n}=2)$. Las áreas sombreadas indican condiciones hipóxicas en el agua de fondo (oxígeno disuelto $<2 \mathrm{mg} / \mathrm{L}$ ). La profundidad del sitio de estudio es de $10 \mathrm{~m}$.

The mean value of organic matter was $18.3 \pm 1.6$ $\%$ (range: $14.2-20.9 \%, \mathrm{n}=63$ ); this suggests an organically enriched sediment. The sediment grain size was relatively stable through the two years of the study and the mean silt/ clay content was high: $77.7 \pm 7.3 \%$ (range: $56.3-96.5 \%, \mathrm{n}=63)$. The chlorophyll $a$ in the surface water fluctuated between 0.5 and $5.2 \mu \mathrm{g} / \mathrm{L}$. Nutrient concentrations were often close to or below quantification limits of the analytical procedures. The maxima concentrations were $\mathrm{N}^{-\mathrm{NO}_{3}}: 4.0 \mu \mathrm{M}, \mathrm{N}-\mathrm{NO}_{2}: 0.29 \mu \mathrm{M}$, $\mathrm{N}-\mathrm{NH}_{4}: 4.5 \mu \mathrm{M}$ and $\mathrm{P}_{-} \mathrm{PO}_{4}: 0.9 \mu \mathrm{M}$.

The pairwise correlations between water column and sediment variables indicated some notable relationships (Table 1). The surface salinity, the dissolved oxygen in bottom water and the depth of the redox potential discontinuity (RPD) were highly correlated. This suggests a mechanism connecting the surface salinity to the hypoxia through the stratification of the water column. The depth of the redox potential discontinuity responds to the oxygen concentration in the bottom water, as indicated by the positive correlation RPD-DO, resulting in shallower RPD depth when dissolved oxygen decreases.

Macrofauna: Over the study period, 817 individuals were collected and identified. Polychaetes were the dominant group in terms of abundance (57\% of total) followed by 
TABLE 1

Spearman rank correlations between the variables measured during two years $(n=20)$

TABLE 1

Correlaciones por rangos de Spearman entre las variables medidas durante los dos años $(\mathrm{n}=20)$

\begin{tabular}{|c|c|c|c|c|c|c|c|c|c|c|}
\hline Variable & $\mathrm{S}_{\mathrm{s}}$ & $\mathrm{S}_{\mathrm{b}}$ & $\mathrm{T}_{\mathrm{s}}$ & $\mathrm{DO}_{\mathrm{s}}$ & $\mathrm{DO}_{\mathrm{b}}$ & Chl $a_{\mathrm{s}}$ & RPD & $\mathrm{S} / \mathrm{C}$ & TOM & $\mathrm{N}$ \\
\hline $\mathrm{S}_{\mathrm{b}}$ & 0.65 & & & & & & & & & \\
\hline $\mathrm{T}_{\mathrm{s}}$ & -0.58 & -0.25 & & & & & & & & \\
\hline $\mathrm{DO}_{\mathrm{s}}$ & 0.33 & 0.19 & -0.43 & & & & & & & \\
\hline $\mathrm{DO}_{\mathrm{b}}$ & 0.84 & 0.41 & -0.66 & 0.62 & & & & & & \\
\hline $\mathrm{Chl} a_{\mathrm{s}}$ & -0.30 & -0.26 & 0.27 & -0.17 & -0.23 & & & & & \\
\hline RPD & 0.67 & 0.32 & -0.52 & 0.51 & 0.70 & -0.48 & & & & \\
\hline $\mathrm{S} / \mathrm{C}$ & -0.08 & 0.16 & -0.07 & 0.01 & 0.01 & -0.09 & 0.19 & & & \\
\hline TOM & -0.07 & -0.08 & -0.20 & 0.44 & 0.04 & -0.28 & 0.38 & 0.28 & & \\
\hline $\mathrm{N}$ & 0.80 & 0.42 & -0.65 & 0.44 & 0.83 & -0.40 & 0.70 & -0.07 & 0.36 & \\
\hline $\mathrm{S}$ & 0.68 & 0.48 & -0.49 & 0.57 & 0.74 & -0.36 & 0.73 & 0.07 & 0.50 & 0.90 \\
\hline
\end{tabular}

$\mathrm{S}_{\mathrm{s}}$ : superficial salinity, $\mathrm{S}_{\mathrm{b}}$ : bottom salinity, $\mathrm{T}_{\mathrm{s}}$ : superficial temperature, $\mathrm{DO}_{\mathrm{s}}$ : superficial dissolved oxygen, $\mathrm{DO}_{\mathrm{b}}$ : bottom dissolved oxygen, Chl $a_{\mathrm{s}}$ : superficial Chlorophyll $a$, RPD: averaged redox potential discontinuity depth $(\mathrm{n}=2)$, S/C: averaged silt/clay fraction $(n=3)$, TOM: averaged total organic matter $(n=3), N$ : averaged macrofauna density (individuals $\left./ 0.1 \mathrm{~m}^{2}\right)$ $(\mathrm{n}=3), \mathrm{S}$ : macrofauna species richness. Correlations larger than 0.7 are in bold type.

$\mathrm{S}_{\mathrm{s}}$ : salinidad superficial, $\mathrm{S}_{\mathrm{b}}$ : salinidad de fondo, $\mathrm{T}_{\mathrm{s}}$ : temperatura superficial, $\mathrm{DO}_{\mathrm{s}}$ : oxígeno disuelto superficial, $\mathrm{DO}_{\mathrm{b}}$ : oxígeno disuelto de fondo, Chl $a_{\mathrm{s}}$ : Clorofila $a$ superficial, RPD: promedio de Profundidad de la Discontinuidad Redox $(\mathrm{n}=2)$, $\mathrm{S} / \mathrm{C}$ : promedio de la fracción limo/arcilla $(\mathrm{n}=3)$, TOM: promedio de la materia orgánica total $(\mathrm{n}=3)$, N: promedio de la densidad de la macrofauna (individuos $\left./ 0.1 \mathrm{~m}^{2}\right)(\mathrm{n}=3)$, S: riqueza de especies de la macrofauna. Se destacan en negrita las correlaciones mayores que 0.7 .

mollusks (41\%). The other $2 \%$ were oligochaetes, decapods, and other crustaceans. Within Polychaeta, the dominant family was Spionidae, comprising over $75 \%$ of polychaete individuals, with Prionospio steenstrupi and Polydora sp .the most abundant species. Amongst mollusks, Tellinidae was the most abundant family with the species Tellina consobrina and Macoma tenta making up over 50 $\%$ of all mollusks.

The grand mean macrofauna density was $52 \pm 61$ individuals $/ 0.1 \mathrm{~m}^{2}$ (range: $0-203$ individuals $/ 0.1 \mathrm{~m}^{2}$ ). The lowest density values occurred in July-November $(9.5 \pm 11.2$ individuals $/ 0.1 \mathrm{~m}^{2}$ ) and the highest in December-June $\left(87.7 \pm 63.7\right.$ individuals $\left./ 0.1 \mathrm{~m}^{2}\right)$. Defaunation occurred in September 2010, October 2010, and September 2011 (Fig. 2A). The grand mean for species richness was $8 \pm 6$ (range: 0-20 species). The highest species richness occurred in April, May and June 2011 (Fig. 2B). Confidence intervals associated to the mean species richness did not overlap between periods of hypoxia and normoxia suggesting significant differences over time.

There were different patterns in the temporal fluctuation of the density of the most abundant polychaete and mollusk species (Fig. 3). SIMPER procedure identified the sets of species that most contribute to the cumulative similarity within two groups of months: hypoxia and normoxia. Only four species contributed to the $90 \%$ of similarity of macrofauna during hypoxia, and eight other species were exclusive of normoxic periods. The mollusks Caecum pulchellum and Parvanachis obesa persisted during the hypoxia events, but during the first few months of subsequent normoxic periods they showed lower densities. They did, however, increase in abundance once normoxia was established (Fig. 3, top panel). Most of polychaete species colonized relatively fast (i.e. $<$ than 1 month) once hypoxia ended. For instance, there were recruitment peaks of 


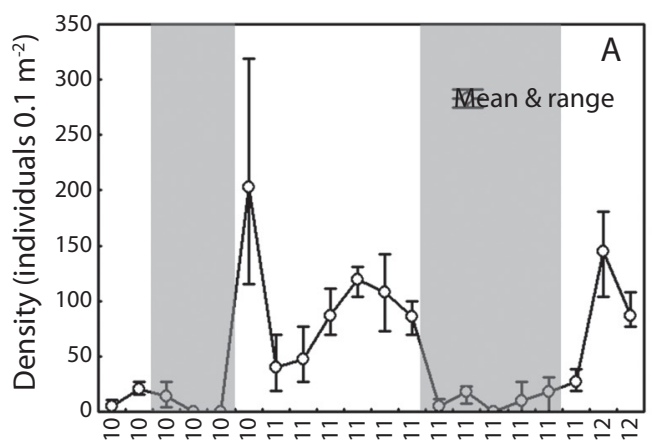

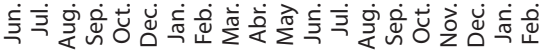

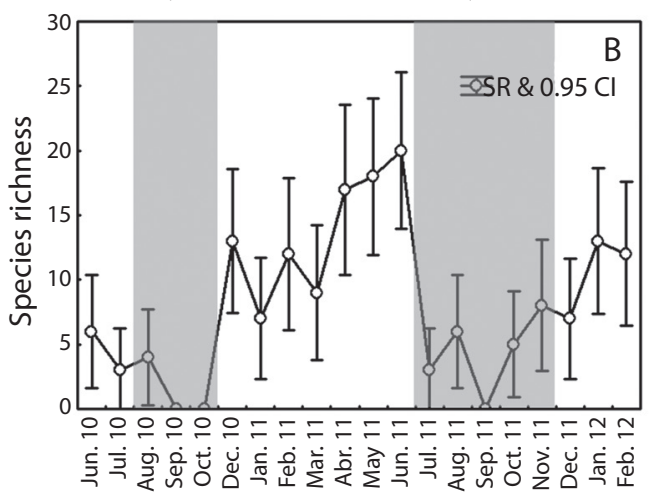

Fig. 2. Temporal fluctuations of macrofauna variables during two years of sampling. (A) Density, (B) Species richness. Note that in November 2010 there are no data. Shaded areas indicate hypoxic conditions in bottom water (dissolved oxygen $<2 \mathrm{mg} / \mathrm{L}$ ).

Fig. 2. Fluctuaciones temporales de las variables de la macrofauna durante los dos años de muestreo. (A) Densidad, (B) Riqueza de especies. No existen datos en Noviembre de 2010. Las áreas sombreadas indican condiciones hipóxicas en el agua de fondo (oxígeno disuelto $<2 \mathrm{mg} / \mathrm{L}$ ).

the polychaetes Prionospio steenstrupi and Polydora sp. in December 2010 and January 2012. The abundance of these species tended to drop after the recruitment peaks (Fig. 3, middle panel). The mollusks Macoma tenta and $T$. consobrina colonized approximately 1-2 months later than the first polychaete peak (i.e. February 2011 and February 2012) (Fig. 3, bottom panel).

The abundance and the species richness of the macrofauna were significantly correlated. There were also high and significant correlations between faunal descriptors and surface salinity, bottom dissolved oxygen and RPD depth (Table 1).

\section{DISCUSSION}

The results of the present study confirm the seasonality of hypoxia, and even anoxia, and its strong influence on the benthic community and sediments. The temporal change in the salinity appears to be the main driver of the stratification of the water column, causing further changes in the chemistry of the water and the sediments. The salinity drop in the wet periods and the slightly cooling of surface waters, compared to bottom, was probable due to the freshwater runoff from the rivers Damuji and Salado, draining directly into the Northern basin. The volume of freshwater inputs into the bay changes inter-annually because of rainfall variability (Muñoz et al., 2008); this may explain the differences in the duration of the stratification between the wet period of 2010 and 2011 (i.e. three and six months, respectively). Temperature did not play a major role in stratification, possibly because of the shallowness of the study site (ca. $10 \mathrm{~m}$ ) and the high heat content of the water, which is typical of tropical semi-enclosed basins (Cheng et al., 2010).

Hydrodynamic processes play key role in the hypoxia of shallow ecosystems (Gray, Shiusun $\mathrm{Wu}, \&$ Ying Or, 2002). Horizontal advection and turbulent mix are weak in Cienfuegos Bay and are caused mainly by tides and winddriven waves (Muñoz et al., 2008). The high contents of organic matter and small particle size indicate that sediments in Calisito are relatively stable and scarcely eroded. Therefore, stagnation of bottom water is plausible during the wet season when wind-driven mixing is weaker. The coupling of low hydrodynamics with the oxidation of the accumulated organic matter is an additional factor beyond salinity stratification that drives seasonal hypoxia in Cienfuegos Bay.

The inventory of organic carbon in Cienfuegos Bay is very high and definitely promotes hypoxia. The nutrient and chlorophyll 
Persistent species
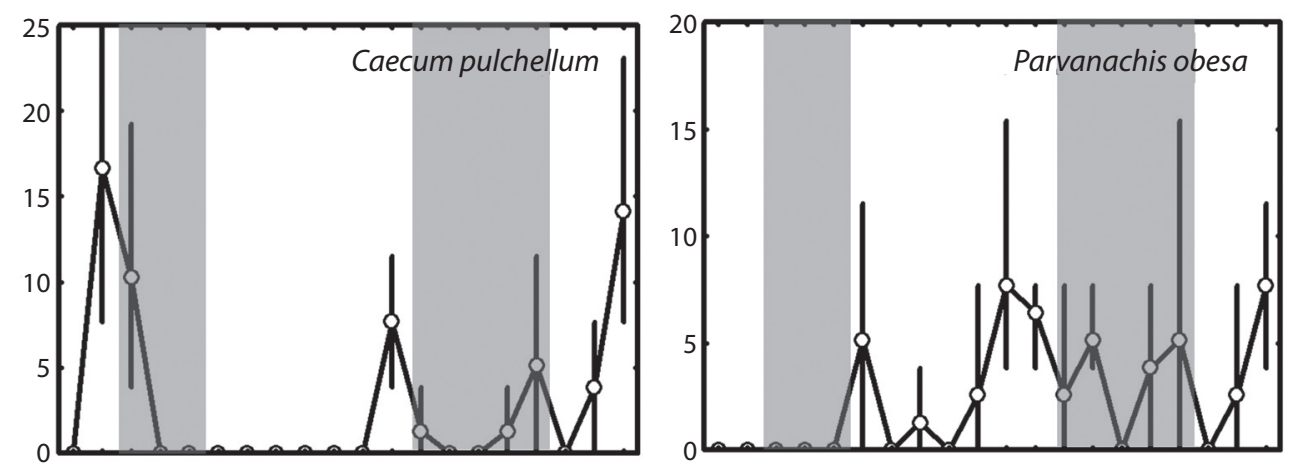

Faster colonizers
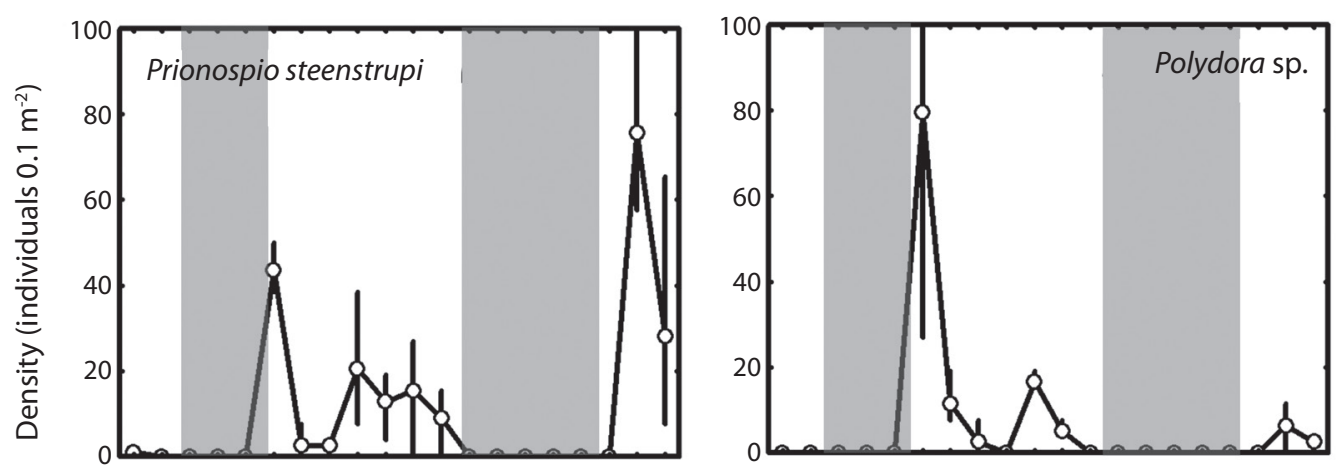

Slower colonizers
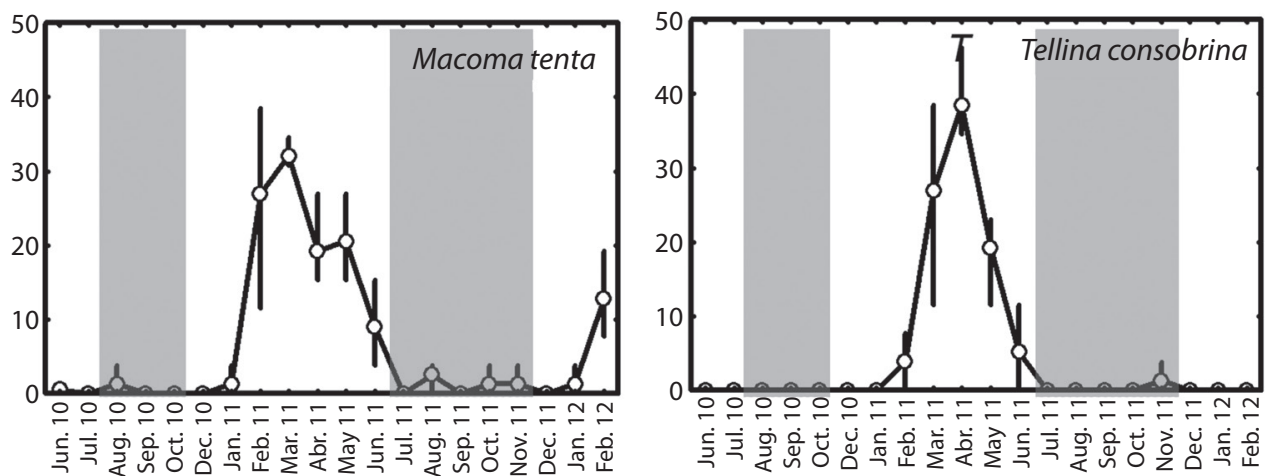

Fig. 3. Temporal fluctuations of the density of six of the most abundant macrofauna species during two years of sampling. Putative patterns of temporal distribution of the species are indicated. Shaded areas indicate hypoxic conditions in bottom water (dissolved oxygen $<2 \mathrm{mg} / \mathrm{L}$ ).

Fig. 3. Fluctuaciones temporales de la densidad de las seis especies más abundantes de la macrofauna durante los dos años de muestreo. Se indican los patrones supuestos de la distribución temporal de las especies. Las áreas sombreadas indican condiciones hipóxicas en el agua de fondo (oxígeno disuelto $<2 \mathrm{mg} / \mathrm{L}$ ). 
a concentrations suggest a medium trophic condition for the water masses (Bricker, Ferreira, \& Simas, 2003); therefore, the contribution of autochthonous sources to the inventory of organic carbon should be lower compared to external sources. Several point and diffuse allochthonous sources of organic matter exist in the Cienfuegos Bay basin; they are mainly related to agricultural and industrial activities (Anonymous 2000). Further studies on the isotopic signature of this organic material would clarify if its origin is autochthonous (e.g. phytoplankton and benthic autotrophs) or allochthonous (e.g. industries, crops).

Our results suggest direct and deleterious effects of hypoxia (and occasionally anoxia) on the abundance and species richness of macrofauna communities in the study site. The distribution patterns of the macrofaunal polychaete assemblages in Cienfuegos Bay have been previously explained by the synergistic effect of low hydrodynamics and the hypoxia derived from organic enrichment (Helguera et al., 2011). The low dissolved oxygen levels impair directly the survival capacity of the macrofauna (Díaz \& Rosenberg, 1995; Seitz et al., 2009). In addition, hydrogen sulfide, a toxic gas associated with hypoxia, may be present and exert major stress on the fauna (Vaquer-Sunyer \& Duarte, 2010). The spionid polychaetes and bivalve mollusks that were the most abundant macrofauna in Cienfuegos Bay are known to be tolerant to moderate or severe hypoxia (Pearson \& Rosenberg, 1978).

In principle, oxygen level data and macrofauna dynamics could be used to indicate the oxygen thresholds for the benthic species. In our study, any estimation of such thresholds would be inaccurate due to the oxygen fluctuations and the difficult of unambiguously identifying the causes of change in the dynamics of benthic populations (Vaquer-Sunyer \& Duarte, 2008). Nevertheless, we identified different suites of species with distinctive response patterns to the seasonal hypoxia.

Persistent species such as $C$. pulchellum and $P$. obesa were present during hypoxia with fluctuating densities and apparently recover to higher abundances when normoxic conditions are re-established. Polychaetes were the pioneer group in the recolonization following improved oxygen conditions (Rosenberg, Agrenius, Hellman, Nilsson, \& Norling, 2002; Vaquer-Sunyer \& Duarte, 2008). The three most abundant polychaetes in the study were the spionids Prionospio steenstrupi, Polydora sp. and Paraprionospio pinnata. These are opportunistic species showing sharp fluctuations in abundance in response to hypoxia abatement (Grassle \& Grassle, 1974; Pearson \& Rosenberg, 1978).

Months after the initial peaks of recruitment, spionid polychaete populations dropped probably due to competition with slower colonizers such as tellinid mollusks. The most abundant tellinid was Macoma tenta; this species occurred mostly as juveniles and has been found elsewhere in high densities during initial recolonization of formerly anoxic areas (Pearson \& Rosenberg, 1978 and references therein). Interestingly, the abundance of colonizer species is reduced consistently 1-2 months in advance of the onset of the seasonal hypoxia. Our interpretation is that competition with persistent species, which recovered during the last period of normoxia, explains this pattern. This putative mechanism underlines that the deleterious effects of hypoxia on the macrofauna are intensified by negative interspecific relationships such as competition by suitable space and predation (Rabalais et al., 2010).

The seasonal recovery of the macrofauna depends considerably on the effective recruitment of larvae into the defaunated areas in the Northern basin. Circulation during the dry period (i.e. normoxic conditions) mainly involves a counter-clockwise pathway and limited exchange with the Caribbean Sea (Tomczak \& García-Díaz, 1975). Furthermore, adjacent habitats in the Caribbean Sea are fundamentally different in structure and functioning (i.e. rocky shores and coastal reefs) and can only minimally serve as a source of soft-bottom macrofauna recruits. We hypothesize that the shallower areas dividing the Southern and Northern basins are an important source of 
macrofauna recruits. Other areas in the Southern basin are more distant and affected by the cell circulation in this basin, making them perhaps less effective as a source of recruits.

In summary, the salinity stratification in the wet period combined with the low hydrodynamics and the oxidation of the accumulated organic matter promote seasonal hypoxia in Cienfuegos Bay. These processes influence the water and sediment geochemistry and reduce both the abundance and diversity of macrofauna. Different suites of species were identified based on the dynamics of persistence/ recruitment: a single mollusk species persist under hypoxia, spionid polychaetes are fast colonizers with initial peaks of recruits, and tellinid mollusks recruit later during normoxia. Recruitment after hypoxia probably depends on the local transport of larvae by currents within the bay.

\section{ACKNOWLEDGMENTS}

The Cuban Ministry of Science, Technology and Environment, Provincial Dependency of Cienfuegos, Project No. 6.03.64 conferred the financial support for this research. This work was partially funded by a research grant A/4004-2 to M.A. from the International Foundation for Science (IFS). We acknowledge the support of the Environmental Analysis Laboratory from the Centro de Estudios Ambientales de Cienfuegos. We would like to thank J. Hernández for English corrections. We also acknowledge to Robert Díaz, Ivan Valiela and anonymous reviewers for the valuable revision of previous versions of the manuscript.

\section{RESUMEN}

Respuesta temporal durante dos años de la macrofauna bentónica y sedimentos a la hipoxia en una bahía semi-cerrada tropical (Cienfuegos, Cuba. La hipoxia es la disminución del oxígeno disuelto por debajo de 2 $\mathrm{mg} \mathrm{O}_{2} / \mathrm{L}$. Relativamente pocos estudios sobre la hipoxia y sus efectos en la macrofauna bentónica han sido realizados en ecosistemas marinos tropicales. Este estudio describe la respuesta temporal de la columna de agua, los sedimentos y la macrofauna a la hipoxia estacional en una bahía semicerrada en Cienfuegos, Mar Caribe. La estación de Calisito fue muestreada mensualmente de Junio 2010 a Febrero 2012, resultando en 21 eventos de muestreo. En cada oportunidad se recolectaron muestras de agua y sedimento para la medición de las variables abióticas (temperatura, salinidad, oxígeno disuelto, discontinuidad del potencial redox, contenido de limo/arcilla y materia orgánica) y macrofauna (abundancia y riqueza de especies). La temperatura y la salinidad superficial presentaron un patrón temporal típico durante los periodos de verano/ lluvia e invierno/seca. Ocurrió estratificación por salinidad en el periodo lluvioso, que duró tres meses en 2010 y seis en 2011. El oxígeno disuelto de fondo indicó eventos de hipoxia y anoxia durante los periodos lluviosos de 2010 y 2011 asociados con la estratificación de la columna de agua, la hidrodinámica lenta y la oxidación de la materia orgánica acumulada. Esto causó efectos deletéreos en la abundancia y diversidad de la macrofauna. Los poliquetos más abundantes fueron especies oportunistas con alta tolerancia a condiciones hipóxicas: Prionospio steenstrupi, Polydora sp. y Paraprionospio pinnata. La mayoría de estos colonizaron relativamente rápido una vez que terminó la hipoxia. Especies persistentes como Caecum pulchellum y Parvanachis obesa estuvieron presentes durante la hipoxia con densidades fluctuantes y aparentemente recuperaron sus abundancias cuando las condiciones normóxicas fueron re-establecidas. Macoma tenta y Tellina consobrina colonizaron 1-2 meses después que el primer pico de poliquetos durante la normoxia. Probablemente, los efectos deletéreos de la hipoxia en la macrofauna fueron intensificados por relaciones interespecíficas negativas como la competencia por espacio y la depredación. La recolonización de la macrofauna dependió probablemente del transporte local por las corrientes dentro de la bahía pues la conexión con el mar Caribe es relativamente limitada. En resumen, la hipoxia estacional en la bahía de Cienfuegos influencia la geoquímica del agua y los sedimentos y reduce la abundancia y diversidad de la macrofauna.

Palabras clave: deficiencia de oxígeno, enriquecimiento orgánico, potencial redox, poliquetos, moluscos, Mar Caribe.

\section{REFERENCES}

Abbott, R. (1974). American Seashells. $2^{\text {nd }}$ edition, Van Nostrand Reinhold: New York.

Anonymous (2000). Informe Final de Proyecto: Manejo Integrado de la Bahía de Cienfuegos. Programa Territorial Científico - Técnico de Medio Ambiente de la Provincia de Cienfuegos.

APHA (1998). Standard methods for the examination of water and wastewater $20^{\text {th }}$ Edition. APHA-AWWAWPCF, Washington DC. 
ASTM (1992). Annual Book of ASTM Standards, Vol. 11.01.American Society for Testing and Materials, Philadelphia.

Bricker, S. B., Ferreira J. G., \& Simas, T. (2003). An integrated methodology for assessment of estuarine trophic status. Ecological Modelling, 169, 39-60.

Cheng, P., Valle-Levinson, A., Winant, C. D., Ponte, A. L. S., Gutierrez de Velasco, G., \& Winters, K. B. (2010). Upwelling-enhanced seasonal stratification in a semiarid bay. Continental Shelf Research, 30, 1241-1249.

Clarke, K. R., \& Gorley, R. N. (2006). Primer v6: User manual/tutorial. Primer-E, Ltd: Plymouth.

Colwell, R. K. (2006). EstimateS: Statistical estimation of species richness and shared species from samples. Version 8.

Díaz-Asencio, L., Armenteros, M., Díaz-Asencio, M., Fernández-Garcés, R., Gómez-Batista, M., \& AlonsoHernández, C. (2009). Spatial and temporal variations of meiofaunal communities in Cienfuegos Bay, Cuba. Revista de Biología Marina y Oceanografia, 44, 13-22.

Díaz, R. J., \& Rosenberg, R. (1995). Marine benthic hypoxia: A review of its ecological effects and the behavioural responses of benthic macrofauna. Oceanography and Marine Biology. An Annual Review, 33, 245-303.

Díaz, R. J., \& Rosenberg, R. (2008). Spreading dead zones and consequences for marine ecosystems. Science, 321, 926-929.

Fenchel, T., \& Riedl, R. J. (1970). The sulfide system: a new biotic community underneath the oxidized layer of marine sand bottoms. Marine Biology, 7, 255-268.

Foster, N. M. (1971). Spionidae (Polychaeta) of the Gulf of Mexico and the Caribbean Sea. Studies of the fauna of Curacao and other Caribbean Islands, 37, 1-138.

Grassle, J. F., \& Grassle, J. P. (1974). Opportunistic life histories and genetic systems in marine benthic polychaetes. Journal of Marine Research, 32, 253-284.

Gray, J. S., Shiu-sun Wu, R., \& Ying Or, Y. (2002). Effects of hypoxia and organic enrichment on the coastal marine environment. Marine Ecology Progress Series, 238, 249-279.

Heiri, O., Lotter, A. F., \& Lemcke, G. (2001). Loss on ignition as a method for estimating organic and carbonate content in sediments: reproducibility and comparability of results. Journal of Paleolimnology, 25, 101-110.

Helguera, Y., Díaz-Asencio, L., Fernández-Garcés, R., Gómez-Batista, M., Guillén, A., Díaz-Asencio, M., \& Armenteros, M. (2011). Distribution patterns of macrofaunal polychaete assemblages in a polluted semi-enclosed bay: Cienfuegos, Caribbean Sea. Marine Biology Research, 7, 757-768.

Howarth, R., Chan, F., Conley, D. J., Garnier, J., Doney, S. C., Marino, R., \& Billen, G. (2011). Coupled biogeochemical cycles: eutrophication and hypoxia in temperate estuaries and coastal marine ecosystems. Frontiers in Ecology and the Environment, 9, 18-26.

Jacinto, G. S., Sotto, L. P. A., Senal, M. I. S., San DiegoMcGlone, M. L., Escobar, M. T. L., Amano, A., \& Miller, T. W. (2011). Hypoxia in Manila Bay, Philippines during the northeast monsoon. Marine Pollution Bulletin, 63, 243-248.

Levin, L. A., Ekau, W., Gooday, A. J., Jorissen, F., Middelburg, J. J., Naqvi, W., Neira, C., Rabalais, N. N., \& Zhang, J. (2009). Effects of natural and humaninduced hypoxia on coastal benthos. Biogeosciences, 6, 3563-3654.

Loring, D. H., \& Rantala, R. T. T. (1992). Manual for the geochemical analysis of marine sediments and suspended particulate matter. Earth Science Review, $32,235-83$

Muñoz, A., Douillet, P., Díaz-García, O., Fichez, R., Herrera, R. H., Alcántara-Carrió, J., \& García, A. (2012). Flushing time in the Cienfuegos Bay, Cuba. Natural Resources Modeling, 25, 434-455.

Muñoz, A., Douillet, P., Díaz-García, O., Ouillon, S., \& Fichez, R. (2008). Influencia de la marea, el viento y el aporte fluvial en la circulación de las aguas de la Bahía de Cienfuegos, Cuba. Revista de Investigaciones Marinas, 29, 101-112.

Pearson, T. H., \& Rosenberg, R. (1978). Macrobenthic succession in relation to organic enrichment and pollution of the marine environment. Oceanography and Marine Biology. An Annual Review, 16, 229-311.

Rabalais, N. N., Diaz, R. J., Levin, L. A., Turner, R. E., Gilbert, D., \& Zhang, J. (2010). Dynamics and distribution of natural and human-caused hypoxia. Biogeosciences, 7, 585-619.

Redfern, C. (2001). Bahamian seashells. A thousand species from Abaco, Bahamas. Boca Raton.

Rosenberg, R., Agrenius, S., Hellman, B., Nilsson, H. C., \& Norling, K. (2002). Recovery of marine benthic habitats and fauna in a Swedish fjord following improved oxygen conditions. Marine Ecology Progress Series, 234, 43-53.

Seisdedo, M. (2006). Variaciones espaciales y temporales en indicadores de la calidad ambiental de las aguas de la Bahía de Cienfuegos, Cuba. Revista de Investigaciones Marinas, 27, 159-164.

Seitz, R. D., Dauer, D. M., Llansó, R. J., \& Long, C. (2009). Broad-scale effects of hypoxia on benthic community structure in Chesapeake Bay, USA. Journal of Experimental Marine Biology and Ecology, 381, S4-S12. 
Tomczak, M., \& García-Díaz, C. (1975). A numerical model of the circulation in Cienfuegos Bay, Cuba. Estuarine and Coastal Marine Science, 3, 391-412.

Vaquer-Sunyer, R., \& Duarte, C. M. (2008). Thresholds of hypoxia for marine biodiversity. Proceedings of the National Academy of Sciences of the United States of America, 105, 15452-15457.

Vaquer-Sunyer, R., \& Duarte, C. M. (2010). Sulfide exposure accelerates hypoxia-driven mortality. Limnology and Oceanography, 55, 1075-1082.

Yoshino, K., Hamada, T., Yamamoto, K., Hayami, Y., Yamaguchi, S., \& Ohgushi, K. (2010). Effects of hypoxia and organic enrichment on estuarine macrofauna in the inner part of Ariake Bay. Hydrobiologia, 652, 23-38.

Zhang, J., Gilbert, D., Gooday, A. J., Levin, L. A., Naqvi, S. W. A., Middelburg, J. J., Scranton, M., Ekau, W., Peña, A., Dewitte, B., Oguz, T., Monteiro, P. M. S., Urban, E. R., Rabalais, N. N., Ittekkot, V., Kemp, W. M., Ulloa, O., Elmgren, R., Escobar-Briones, E., \& Van der Plas, A. K. (2010). Natural and humaninduced hypoxia and consequences for coastal areas: synthesis and future development. Biogeosciences, 7, 1443-1467. 